Dlatego zasadniczo gest Eliasza nie stanowi nowej zasady ani prawa dotyczącego oczyszczenia odmiennego od praw ustanowionych przez ustawodawstwo kapłańskie. Gest Eliasza pokazuje, że taka sama zasada może działać w wymiarze międzyludzkim i żadna ofiara ze zwierzęcia jej nie dorówna.

Tak więc pozorne naruszenie przez Eliasza Prawa (dotknięcie zwłok) nakłoniło do głębszego rozważenia jego modlitwy wstawienniczej i samoofiarowania się. W rzeczy samej oddanie Eliasza domowi wdowy i jego wstawiennictwo umieszczają jego gest w sferze innej niz ta, w której działają normalne prawa czystości-nieczystości. A zatem można wyciągnąc wniosek, że Eliasz biorąc na siebie rolę ofiary a wynika to $\mathrm{z}$ jego utożsamieniem się $\mathrm{z}$ ostateczną nieczystością śmierci - przyniósł życie dziecku wdowy.

Gorzów Wlkp.

Ks. MIECZYSEAW MIKOEAJCZAK

Ks. Marian Machinek MSF

\title{
KAZANIE NA GÓRZE. PROFETYCZNA PROWOKACJA CZY PROGRAM ŻYCIOWY? ${ }^{1}$
}

Istnieją w historii ludzkości teksty, które wywierały ogromny wpływ na losy pojedynczych ludzi i całych narodów. Chrześcijaństwo zna również taki tekst, tekst, który od prawie dwudziestu wieków pobudzał całe generacje uczniów Jezusa do podejmowania radykalnych życiowych wyborów. Chodzi o tzw. Kazanie na Górze, które określane jest jako „Magna Charta” nauki chrześcijańskiej, jako „prawo Królestwa Bożego”. Te określenia pozwalają przeczuć, jakie znaczenie przypisywano temu tekstowi i jak ogromny potencjał kryją $\mathrm{w}$ sobie te trzy rozdziały mateuszowej Ewangelii. Zajmowanie się Kazaniem na Górze nie należy do żądań łatwych. Historia chrześcijaństwa wypracowała całe mnóstwo interpretacji Kazania na Górze, zarówno bardzo radykalnych, jak również bardzo redukcjonistycznych. Nie sposób jednak oprzeć się fascynacji, jaką ten tekst wywiera na

${ }^{1}$ Artykuł niniejszy jest przepracowanym tekstem wykładu inauguracyjnego, wygłoszonego przez autora na uroczystości inauguracji roku akademickiego 1997/1998 w Wyższym Seminarium Duchownym Misjonarzy Świętej Rodziny w Kazimierzu Biskupim k/Konina. 
kimś, kto stara się zgłębić jego treść. Opracowanie niniejsze pragnie najpierw przytoczyć kilka danych egzegetycznych, które zdają się mieć znaczenie przy interpretacji tego tekstu. Aby zająć stanowisko wobec alternatywy sformułowanej w tytule, zostaną najpierw przedstawione niektóre interpretacje Kazania na Górze, które zostaną poddane krytycznej analizie.

\section{KILKA DANYCH WSPÓŁCZESNEJ EGZEGEZY}

Ramy niniejszego artykułu nie pozwalają na egzegetyczną analizę poszczególnych części Kazania na Górze. Taką analizę znaleźć można w obszernych komentarzach do Ewangelii Mateusza, np. w ramach niemieckojęzycznego obszaru takich egzegetów jak Ulrich Luz, Joachim Gnilka, czy Alexander Sand. W niniejszym opracowaniu będzie chodziło o podanie kilku myśli, mających - jak się wydaje - kluczowe znaczenie dla rozumienia znaczenia „mowy mów”.

Po pierwsze - motyw góry. Motyw ten, od którego pochodzi nazwa całego tekstu ${ }^{2}$, pojawia się na wstępie (Mt 5, 1f) i na końcu (Mt 8, 1) tekstu i zdaje się być jednym z kluczowych szczegółów, ilustrujących zamiar Ewangelisty. W tekście, który Mateusz pragnie przedstawić, nie będzie chodziło o jedno $\mathrm{z}$ wielu przemówień Jezusa, a niejako o tekst programowy, o wielką proklamację mesjańskiej Tory. Jezus przyjmuje postawę siedzącą, charakterystyczną dla żydowskiego rabbiego, który „otwiera swoje usta”, aby nauczać zgromadzonych u jego stóp uczniów. W motywie góry nie sposób nie dostrzec aluzji do Synaju i do ogłoszonego tam Prawa. Tłum zgromadzony u stóp góry nie jest w zamiarze mateuszowym przypadkowo zebraną grupą ludzi.

Tutaj należy poruszyć drugie zagadnienie, mianowicie pytanie o adresatów Kazania na Górze. Aby odszyfrować zamiar Ewangelisty, trzeba cofnąc się kilka wierszy wstecz i przyjrzeć się z jakich części Palestyny pochodzi tłum, zgromadzony u stóp Góry Błogosławieństw. Mateusz podaje stosunkowo dokładne nazwy geograficzne, które, jak twierdzi znany niemiecki egzegeta, Gerhard Lohfink, nie są przypadkowe i są nośnikami idei teologicznej Ewangelisty. Lohfink zauważa najpierw, że zdania zawarte w Mt 4, 23 i Mt 9, 35 odpowiadają sobie prawie dosłownie (Jezus obchodzi miasta i wioski, naucza, głosi Ewangelię o Królestwie i leczy wszystkie choroby i słabości). Właśnie te dwa prawie identycznie brzmiące zdania stanowią, zdaniem Lohfinka, zewnętrzną ramę, w obrębie której należy szukać odpowiedzi na pytanie o adresatów Kazania na Górze, pytanie, które

${ }^{2}$ Nazwę „Kazanie na Górze” zawdzięczamy św. Augustynowi, który zatytułował swój komentarz De sermone Domini in monte (PL 34[1887], 1229-1308). Zob. także H. M e r k l e i n, Bergpredigt, [w:] RGG ${ }^{3}$, Bd. I, s. 255. 
jest kluczem do zrozumienia całego tekstu. W myśl tego założenia Lohfink analizuje nazwy geograficzne, zawarte w Mt 4, 23. Ewangelista podaje niektóre nazwy $\mathrm{w}$ oparciu o dostępną mu tradycję markową, nie trzyma się jednak kurczowo markowego tekstu, ale zmienia go, skreślając niektóre nazwy geograficzne, a dodając inne. Czy zabieg ten jest przypadkowy? Lohfink twierdzi, że nie. Do czego Ewangelista dąży, jest niejako naszkicować mapę całego Izraela z czasów dawidowej świetności. W ten sposób powstaje wrażenie, że lud zgromadzony pod Górą Błogosławieństw pochodzi ze wszystkich geograficznych części Palestyny, które tradycja rabinistyczna używała dla opisania całego Izraela. Lud ten jest więc niejako reprezentacją Narodu Wybranego, któremu nie tylko będzie dane usłyszeć ostateczną interpretację Tory, proklamowaną z Autorytetem, przewyższającym autorytet Mojżesza, ale który będzie się musiał opowiedzieć za albo przeciw tej proklamacji. Gdyby przyjąć wywody Lohfinka za trafne, wtedy Kazanie na Górze urasta faktycznie do rangi centralnego nauczania Ewangelii, nauczania, które - według mateuszowej teologii - będzie ogłoszone wszystkim narodom (zob. nakaz misyjny w Mt 28, 20), po tym, jak Naród Wybrany je odrzuci (zob. Mt 27,25$)^{4}$. Można jednakowoż zapytać, czy Kazanie na Górze ma w ogóle coś wspólnego z żydowskim Prawem? Czyż Jezus nie zniósł żydowskiego prawa $\mathrm{i}$ nie proklamował na to miejsce swojej Ewangelii?

Tutaj pojawia się trzecia kwestia - pytanie o stosunek Jezusa do Tory, do żydowskiego Prawa. Pytanie to jest o tyle skomplikowane, iż Nowy Testament dostarcza nam wystarczająco dużo tekstów, które zdają się zarówno podkreślać wielki szacunek Jezusa do Tory, jak i wielką jego suwerenność wobec poszczególnych przepisów prawnych. Odpowiednio ekstremalne pozycje zajmują też poszczególni egzegeci. Wydaje się jednak, że Jezus nigdy nie głosił pryncypialnego zniesienia prawa, szczególnie w jego wymiarze moralnym, chociaż nie kładł nacisku na przestrzeganie prawnych przepisów rytualnych. Taką też opcję sugeruje Mateusz, gdy w Mt 5, 17 umieszcza słowa Jezusa: „Nie sądźcie, że przyszedłem znieść Prawo i Proroków. Nie przyszedłem znieść, ale wypełnić". Na czym polega to wypełnienie

${ }^{3}$ Według Ulricha Luza Mt 5, 23-25 są sformułowane na podstawie następujących tekstów markowych: 1, 39 (Mt 4, 23); 1, 28.32.34 (Mt 4, 24); 3, 7 n (Mt 4, 25). Zob. U. L u z, Das Matthäusevangelium (EKK, I/1), Zürich 1992, s. 179.

${ }^{4}$ Szczegółowe uzasadnienie tej tezy znajduje się [w:] G. L o h f i n k, Wem gilt die Bergpredigt? Eine redaktionskritische Untersuchung von Mt 4, 23-5, 2 und 7, 28f, [w:] Das Gesetz im Neuen Testament, hrsg. K. Kertelge, Freiburg-Basel-Wien 1984, s. 145-167; tenże, Wem gilt die Bergpredigt? Zur Glaubwürdigkeit der Christen, Freiburg i. Br. 1993, s. 18-38. 
Prawa przez Jezusa? Jezus ukazuje niejako pierwotny zamiar Boga, stojący u źródeł nakazów Prawa, które Izrael zaciemnił przez całe mnóstwo drobiazgowych przepisów. Posługując się nowoczesną terminologią można by powiedzieć, że Jezus proklamuje nową hermeneutykę prawa, która jednakowoż nie jest po prostu jedną z interpretacji, ale interpretacją ostateczną, ogłoszoną z mesjańskim autorytetem, przewyższającym wszystkie inne sposoby rozumienia Tory. Poglądy dopatrujące się zniesienia żydowskiego Prawa przez Jezusa zdają się nie brać poważnie faktu, iż był On, jako człowiek, mocno związany $\mathrm{z}$ teologiczną tradycją swego narodu ${ }^{5}$.

I jeszcze ostatnie, czwarte pytanie, jakie trzeba zadać egzegezie, pytanie o literacka strukturę tekstu Kazania na Górze. Egzegeci dawno dostrzegli fakt, że Kazanie na Górze nie jest po prostu zlepkiem tekstów, tylko że posiada ono głęboko przemyślaną, filigranową strukturę literacką, która sama w sobie już wskazuje na teologiczne akcenty Ewangelisty. Z dostępnego sobie materiału, zawierającego mowy Jezusa (między innymi tradycji źródła Q, tradycji markowej oraz tradycji własnej, przekazywanej w mateuszowych wspólnotach) Ewangelista komponuje „Kazanie kazań”.

Z wielu propozycji struktury literackiej Kazania na Górze zostanie przedstawiona tylko jedna, mianowicie propozycja sformułowana przez Ulricha Luza. Uważa on, że Kazania na Górze jest typowym przykładem chiastycznej kompozycji pierścieniowej, w której materiał zgrupowany jest wokół jakiegoś centralnego tekstu. Element środkowy, który wyznacza oś całego tekstu i leży w jego centrum, posiada też dla tekstu wielkie znaczenie i jest niejako „kluczem” do jego zrozumienia. Jak widać na schemacie (s. 4) tym centralnym elementem jest dla Luza w Kazaniu na Górze modlitwa „Ojcze nasz” (Mt 6, 7-15), która faktycznie leży dokładnie w jego centrum ${ }^{6}$. U podstaw schematu Luza stoją takie cechy tekstu, jak np. podobieństwa w długości odpowiadających sobie części (np. 56 linijek greckiego tekstu (Nestle) odpowiednio w Mt 5, 21-48 i Mt 6, 19-7, 1), czy też używa-

${ }^{5}$ Pytanie o stosunek Jezusa do Tory jest bardzo szeroko dyskutowane. Zob. poza odpowiednimi rozdziałami w wymienionych wyżej komentarzach do Ewangelii mateuszowej także: J. B e c k e r, Das Ethos Jesu und die Geltung des Gesetzes, [w:] Neues Testament und Ethik, hrsg. H. Merklein, Freiburg-Basel-Wien 1989, s. 37; J. L a m b r e c h t, Gesetzesverständnis bei Paulus, [w:] Das Gesetz im Neuen Testament, hrsg. K. Kertelge, FreiburgBasel-Wien 1984, s. 90; G. S t r e c k e r, Die Bergpredigt. Ein exegetischer Kommentar, Göttingen 1984, s. 57.

${ }^{6}$ Również inni egzegeci zauważyli centralne znaczenie Modlitwy Pańskiej dla rozumienia Kazania na Górze. Zob. W. G r u n d m a n n, Das Evangelium nach Matthäus (ThHK, 1), Berlin 1968, s. 204-206; R. S c h n a ck e n b u r g, Alles kann, wer glaubt. Bergpredigt und Vaterunser in der Absicht Jesu, Freiburg i. Br. 1984, s. 85nn. 
nie tych samych zwrotów (np. „Królestwo Niebios” w M 5, 3-16 i 7, 13-27). Mateusz grupuje też często swój materiał według systemu trójkowego ${ }^{7}$. Chiastyczna struktura Kazania na Górze wg Ulricha Luza przedstawia się następująco ${ }^{8}$ :

$$
\begin{aligned}
& \text { A } 5,1 f \quad K l a m r a \text { (sytuacja) } \\
& \text { B 5, 3-16 Wprowadzenie (Einleitung) } \\
& \text { C 5, 17-20 Introitus } \\
& \text { D 5, 21-48 Cześć główna (Antytezy) }
\end{aligned}
$$

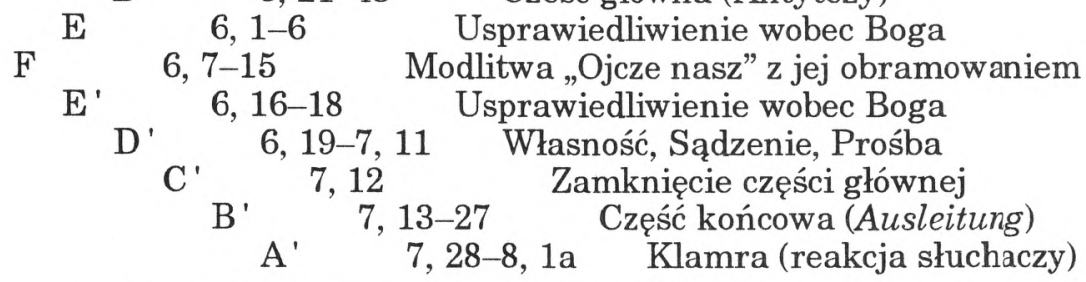

Reasumując można powiedzieć, że Kazanie na Górze miało w zamyśle Ewangelisty centralne znaczenie, na co wskazuje bardzo kunsztowna budowa tekstu, jak również sceneria, w której mowa Jezusa się dokonuje. Historia wykładu tego tekstu w ciągu dziejów może jedynie potwierdzić określenie, które mu nadano: Magna Charta nauki chrześcijańskiej.

\section{INTERPRETACJA KAZANIA NA GÓRZE: MIĘDZY RADYKALIZMEM A SCEPTYCYZMEM}

Od samego początku Kościoła Kazaniu na Górze towarzyszyło pytanie: Czy podane tu reguły postępowania są w ogóle wykonalne? Egzegeza mówi nam, że radykalne wymagania etyczne Jezusa były w okresie powielkanocnym przekazywane przez wędrownych kaznodziejów, którzy faktycznie uczynili je regułą ich życia (niem. „Wanderradikalismus"). Nakazy moralne Jezusa stanowiły dla nich jakby podręcznik. Ich styl życia charakteryzował się opuszczeniem rodziny i ojczyzny, ubóstwem i wyrzeczeniem się wszelkiej przemocy, co miało być czytelnym znakiem nadchodzącego Królestwa ${ }^{9}$. Również inne

${ }^{7} \mathrm{~Np}$. dwa razy trzy antytezy, trzy reguły ascetyczne itd. Luz wskazuje nawet na zaskakującą zgodność $\mathrm{w}$ długości odpowiadających sobie części tekstu (ilość słów). Zob. U. L u z, Matthäus, Bd. I/1, s. 23n., s. 185-187.

${ }^{8}$ Schemat niniejszy jest uproszczoną wersją schematu, który Luz zamieścił w swoim komentarzu. Zob. U. L u z, Matthäus, T. I/1, s. 186.

9 Zbadaniem początków działalności misjonarskiej uczniów Jezusa w okresie powielkanocnym, skierowanej jeszcze bardzo mocno w kierunku narodu izraelskiego („Wanderradikalismus”) zajął się G. T h e i s s e n, Stu- 
fragmenty Ewangelii, jak. np. Mk 6, 8-11; Mt 10, 5-15; Łk 9, 2-5, formułujące warunki wejścia do królestwa Bożego, czy też warunki pracy misyjnej uczniów, były w ciągu historii często interpretowane jako zasady odnoszące się jedynie dla niewielu powołanych. Już jednak Kościoły pierwszych wieków borykały się z ogromnymi trudnościami przy dosłownej interpretacji Kazania na Górze.

\section{KODEKS PRAWNY?}

Szczególnie tam, gdzie poziom życia chrześcijan zaczął odbiegać od wysokich chrześcijańskich ideałów, pojawiały się radykalne ruchy, które próbowały traktować Kazanie na Górze jako coś w rodzaju kodeksu postępowania, którego poszczególne zasady należałoby bez jakichkolwiek interpretacji wcielić w życie. I rzeczywiście, trudno odmówić takim poglądom ziarna prawdy, bo chrześcijaństwo jest z zasady swej radykalne. Życie jednak pokazało, że społeczeństwa, w których próbowano by znieść całkowicie sądy, policje, wojsko i jakąkolwiek własność, jak tego domagał się np. Lew Tołstoj, powołując się na Kazanie na Górze, nie byłyby zdolne do przeżycia.

Patrząc na całość Ewangelii mateuszowej trzeba stwierdzić obecny w niej bardzo mocny nacisk na czyn płynący z wiary, który decyduje o autentyczności wiary chrześcijańskiej. Chociaż pewne pokrewieństwo w stosunku do żydowskiej tradycji (w tym także tradycji etycznej) cechuje mniej lub bardziej każdą z ksiąg Nowego Testamen$\mathrm{tu}^{10}$, to jednak pokrewieństwo to osiąga swoją kulminację właśnie w Ewangelii mateuszowej, w zdecydowanej, potwierdzonej przez uroczyste „Amen” deklaracji wiecznego trwania Tory w Mt 5, 18: „Dopóki niebo i ziemia nie przeminą, ani jedna jota, ani jedna kreska nie zmieni się w prawie, aż się wszystko spełni". Nic nie wskazuje na istnienie antynomistycznych tendencji w łonie mateuszowej tradycji, które by obowiązywanie zasad moralnych pozostawiły niezależnej decyzji pojedynczego ochrzczonego. Co więcej, niektóre uzupełnienia w tekście samego Kazania na Górze zdają się być śladem starochrześcijańskiej kazuistyki, tzn. próbą dostosowania wysokich norm etycznych do konkretnej sytuacji życiowej (jak np. tzw. klauzula mate-

dien zur Soziologie des Urchristentums (WUNT, 19), Tübingen 1979, s. 79-105 .

${ }^{10}$ Według Klausa Bergera autorzy wszystkich ksiąg Nowego Testamentu zakładają znajomość Prawa przez swoich adresatów (nawet wtedy, gdy Prawo poddane jest u nich krytyce!), a więc muszą wywodzić się z tradycji żydowskiej. Dopiero Ignacy z Antiochii, Polikarp i Autor Listu Diogeneta są teologami chrześcijańskimi pochodzącymi z pogaństwa. Zob. K. B e $\mathbf{r}$ g e r, Theologiegeschichte des Urchristentums. Theologie der Neuen Testaments, Tübingen-Basel 1994, s. 17. 
uszowa - Mt 5, 32). Nie ulega więc wątpliwości, że Kościół pierwszych wieków traktował nakazy moralne Kazania na Górze bardzo poważnie i próbował wcielić je w życie.

Z drugiej jednak strony nie da się uczynić z Kazania na Górze zbioru przepisów regulujących życie codzienne. Pouczenia moralne przybierają tu zarówno postać reguł postępowania, jak i przypowieści, błogosławieństw, jak i przykładów, których bogactwa nie dało by się zawrzeć w suchych regułach prawnych ${ }^{11}$. Podkreślić trzeba bardzo mocno, że wymagania moralne Jezusa zobowiązują człowieka w zupełnie inny sposób, niż przepisy prawa. Jezus nie tylko wymaga, On umożliwia spełnienie wymagań. Moralność Ewangelii zakłada odnowione człowieczeństwo, które jest w stanie podołać wymaganiom Jezusowym, bo On sam uzdalnia do ich spełnienia. Dlatego też Kazanie na Górze nie rozpoczyna się wyliczaniem przykazań, ale ośmioma błogosławieństwami, które najpierw proklamują darmowa łaskę Boga, a dopiero potem stawiają wymagania. Kazanie na Górze nie chce pełnić roli „podręcznika” zawierającego szczegółowe reguły postępowania w każdej sytuacji. Cała jego siła polega na mocnym impulsie moralnym, który jednak nie może ograniczyć się do dosłownego zastosowania podanych $\mathrm{w}$ tekście reguł. Ale czy są one w ogóle wykonalne?

\section{NIEWYKONALNE REGUŁY?}

„Dla Mateusza jak również dla całego Kościoła aż do okresu poreformatorskiego było jasne, że Kazanie na Górze jest wykonalne"12. To zdanie Ulricha Luza nie pozwala absolutyzować stwierdzenia, że Kazanie na Górze nie jest kodeksem reguł prawnych. Tradycja protestancka próbowała rozwiązać problem praktycznego zastosowania zasad Kazania na Górze właśnie w ten sposób, że określiła je jako niewykonalne dla grzeszników. Co więcej, tradycja ta stwierdziła, że nakazy moralne Kazania na Górze zostały dane nie po to, aby je dokładnie zastosować w życiu, ale, aby człowiek, doświadczywszy swojej słabości wobec moralnych nakazów Boga, przekonał się wreszcie, iż potrzebuje usprawiedliwiającej łaski. Teza ta ma swoje źródło w nauce Marcina Lutra o roli Prawa, którą sformułował on na podstawie

${ }^{11}$ Zob. H. S c h ü r m a n n, Moraltheologische Ansätze in den Mahnungen und Weisungen Jesu. Questiones disputatae, ThG 72 (1982) s. 449. H. Merklein przypomina, że traktowanie wypowiedzi Jezusa jako zasad prawnych stoi w sprzeczności z główną myślą Ewangelii. W centrum etyki Jezusa stoi człowiek, a nie ustawy prawne. Zob. H. M e r k l e i n, Gottesherrschaft als Handlungsprinzip. Untersuchung zur Ethik Jesu, Würzburg 1978, s. 298.

${ }^{12}$ U. L u z, Matthäus, Bd. I/1, s. 188. 
własnej egzegezy Listów pawłowych. Tzw. drugorzędna funkcja prawa (secundus usus legis) polega na tym, że nakazy moralne prawa stają się dla człowieka niejako „zwierciadłem grzechu” (speculum peccati), ponieważ są dla niego zbyt trudne i niewykonalne. W ten sposób prawo powiększa jedynie świadomość grzeszności człowieka i ostatecznie każe mu paść na kolana przed Bogiem i przyznać, że nie sposób osiągnąć usprawiedliwienia z uczynków ${ }^{13}$.

Takie określenie roli Kazania na Górze jest błędne. Nic nie wskazuje na to, aby Jezus (czy też pierwsze wspólnoty chrześcijańskie, które przekazywały Jego słowa), pragnął postawić niewykonalne zasady moralne. Fakt, że wymagania te są bardzo wysokie i że człowiek próbujący nimi żyć często doświadcza swojej słabości, nie uprawnia do tego, aby określić je jako absolutnie niewykonalne. Ich radykalizm był jednakowoż zawsze wielkim problemem.

Warto tu wspomnieć o innej jeszcze tezie w obrębie tradycji protestanckiej, dotyczącej pytania o zastosowanie zasad Kazania na Górze. Chodzi tu o tzw. "naukę o dwóch Królestwach" (Zwei-Reiche-Lehre) Marcina Lutra. Tradycja luterańska odrzuciła wprawdzie radykalnie wszelkie różnice miedzy poszczególnymi kategoriami ochrzczonych (np. między „zwyczajnymi” wiernymi, a tymi, którzy żyją w tzw. „stanie doskonałości”), ale za to wprowadziła niejako rozdwojenie pojedynczego ochrzczonego, w zależności do tego, czy działa on jako osoba prywatna, czy też spełnia jakiś urząd publiczny. Podczas gdy pojedynczy ochrzczony jako osoba prywatna („Privatperson”) może sobie pozwolić na bardzo radykalne zastosowanie Kazania na Górze, włącznie $\mathrm{z}$ pacyfizmem i odrzuceniem zemsty, ten sam ochrzczony, gdy spełnia jakiś urząd państwowy („Weltperson”), musi kierować się nie miłością a sprawiedliwością i nie może „sobie pozwolić” na zastosowanie zasad Kazania na Górze. Teza ta wprawdzie ilustruje dobrze konflikty sumienia wielu chrześcijan, którzy uczestniczą w życiu publicznym, ale nie znajduje żadnego uzasadnienia w tekście Kazania na Górze. Co więcej, konsekwentne zastosowanie tej tezy doprowadziło by do tego, że radykalizm ewangeliczny stałby się prywatną sprawą pojedynczych ludzi, podczas gdy życie społeczne byłoby regulowane zasadami utylitaryzmu. „Jezus nie rozszczepia człowieka na dwie części czy dwa wymiary", - stwierdza Wolfgang Schrage - „aby mógł on się zasłonić rolą, jaką spełnia, instytucja, czy instancja, i zwolnić się z odpowiedzialności, wskazując na zewnętrzne naciski"14.

${ }^{13} \mathrm{O}$ różnych funkcjach prawa u Lutra zob.: M. L u t h e r, In epistolam S. Pauli ad Galatas Commentarius (WA 40/1, 579, 11.30). Zob. też O. H. $\mathrm{P}$ e s c h, Thomas von Aquin. Das Gesetz (Die deutsche Thomas-Ausgabe, 13), Heidelberg-Graz-Wien-Köln 1977, s. 665-666.

${ }^{14} \mathrm{~W}$. S c h r a g e, Ethik des Neuen Testaments (Grundrisse zum Neuen Testament, 4), Göttingen ${ }^{4} 1982$, s. 91-92; zob. też P. H of f m a n n, Eschato- 


\section{ETYCZNE „PROWIZORIUM”?}

Jeszcze inną próbą „rozbrojenia” radykalnych wymagań Kazania na Górze jest przesadne podkreślanie ich eschatologicznego wymiaru. Wymiaru tego nie da się wprawdzie całkiem wykluczyć, ponieważ pierwotne chrześcijaństwo żyło faktycznie w świadomości „końca czasów" i w oczekiwaniu rychłej paruzji. Właśnie tą eschatologiczną świadomością próbuje się wyjaśnić radykalizm Kazania na Górze. Jego zasady moralne byłyby jedynie ,etyką stanu wyjątkowego", przewidzianą na krótki czas ostatecznej walki ${ }^{15}$, swego rodzaju „etycznym prowizorium”, a nie zasadami chcącymi na dłuższy czas regulować współżycie ludzi, czy być źródłem reguł postępowania w „normalnej” rzeczywistości. Radykalizm Kazania na Górze nie obowiązywałby naturalnie chrześcijan wszystkich czasów, ze względu na fakt, iż powtórne przyjście Pana nie nastąpiło tak szybko, jak tego oczekiwały pierwsze gminy chrześcijańskie. W języku niemieckim przyjęło się pojęcie „Interimsethik” na określenie tej koncepcji teologicznej. Słowo „interim” oznacza tutaj krótki odcinek czasu między zapowiedzią nadejścia Królestwa Bożego przez Jezusa, a jego faktycznym przyjściem, czyli końcem dziejów. Radykalne nakazy etyczne Jezusa byłyby przeznaczone tylko na ten krótki „międzyczas”, jednak próba ich zastosowania w normalnym społeczeństwie nie miałaby sensu.

Z jednej strony trzeba przyznać, że nakazy moralne Nowego Testamentu zawdzięczają swoją dynamikę właśnie eschatologicznej perspektywie. Bliskość Królestwa Bożego stwarza konieczność dokonania radykalnych i nie cierpiących zwłoki wyborów. Jednak gdyby się chciało tłumaczyć radykalizm moralny Jezusa jedynie perspektywą eschatologiczną, trzeba by traktować go jako swego rodzaju „proroka zagłady”, który głosiłby swoją naukę niejako „w blasku ognia nadciągającej katastrofy" (G. Bornkamm). Obraz ludzi, którzy porzucają wszystko, bo i tak nie warto zajmować się ziemskimi sprawami, gdy apokaliptyczna katastrofa jest już blisko, taki obraz nie odpowiada duchowi Ewangelii. Wydaje się, iż wymiar eschatologiczny Ewangelii byłby wypaczony, gdybyśmy wyobrażali sobie Jezusa i jego uczniów jako ludzi ogarniętych gorączkowym oczekiwaniem rychłego końca świata ${ }^{16}$.

logie und Friedenshandeln in der Jesusüberlieferung, [w:] Eschatologie und Friedenshandeln (SBS, 101), Stuttgart 1981, s. 150.

${ }^{15}$ Zob. J. W e i B, Die Predigt Jesu vom Reiche Gottes, Göttingen ${ }^{3} 1964$, s. 150. Podobnego zdania byl też Albert Schweitzer.

${ }^{16}$ Zob. J. G n i $1 \mathrm{k}$ a, Jesus von Nazareth. Botschaft und Geschichte (Herder TKNT Suppl., 3), Freiburg-Basel-Wien 1990, s. 174; W. S c h r a g e, Ethik, s. 33-40; H. M e r k le i n, Gottesherrschaft, s. 168n. 
Określenie to pragnie być odpowiednikiem niemieckiego terminu „Gesinnungsethik"17. Zwolennicy takiej koncepcji etycznej uważają, iż Jezus postawił pod znakiem zapytania wszystkie dotychczasowe normy moralne i zaapelował jedynie do sumienia poszczególnego człowieka. Jedynie wewnętrzna postawa, wewnętrzne przekonanie, mają znaczenie, a nie zewnętrzne czyny. Obiektywna moralność, związana z ogólnie obowiązującymi normami, stałaby się niepotrzebna, a nawet szkodliwa. Koronnym argumentem zwolenników tej koncepcji jest częste podkreślanie przez Jezusa sfery „serca”, gdzie dokonują się osądy moralne, gdzie mają swoje źródło zarówno dobre jak i złe czyny, jak również Jezusowa krytyka obłudy, kładącej ogromny nacisk na zewnętrzne przestrzeganie prawa. Kazanie na Górze, widziane w takiej perspektywie, nie może być traktowane jako źródło konkretnych zasad moralnych. Jezus nie żąda w ogóle przestrzegania konkretnych norm moralnych, twierdzi $R$. Bultmann, a jedynie radykalnego posłuszeństwa wobec woli Bożej. To posłuszeństwo jednak przyjmowałoby według Bultmanna różną postać, zależnie od konkretnej sytuacji ${ }^{18}$.

Koncepcja ta, zdająca się tak dobrze odpowiadać świadomości moralnej niezależności współczesnego człowieka, nie da się jednak pogodzić z poglądami moralnymi wczesnochrześcijańskich wspólnot. Oznacza ona praktycznie etykę sytuacyjną, która jest $\mathrm{w}$ stanie usprawiedliwić każdy czyn człowieka, jeżeli tylko jego wewnętrzna motywacja jest odpowiednia. Jako przykład mogą tu posłużyć poglądy Josefa Fletchera, który w latach sześćdziesiątych przedstawił koncepcję nowej moralności, opartej jedynie na przykazaniu miłości, przy czym każdy miałby prawo ową miłość inaczej rozumieć. Jeżeli np. miłość wymagałaby uśmiercenia drugiego człowieka, czy też zdrady małżeńskiej, czyny te byłyby dozwolone. Chociaż nie sposób odmówić słuszności stwierdzeniu, że miłość jest fundamentem etyki chrześcijańskiej, to jednak nigdy nie jest to miłość „bezkształtna”. Musi być ona rozumiana w świetle życia i postępowania Jezusa Chrystusa. Nie trzeba udowadniać, że koncepcja etyki sytuacyjnej nie ma żadnych podstaw ani w słowach i czynach Jezusa, ani w praktyce wspólnot nowotestamentalnych. Wspólnoty te rozumiały i przekazywały słowa Jezusa jako zasady etyczne, domagające się konkretnego wypełnienia

${ }^{17}$ Odnośnie do terminu „Gesinnungsethik” zob.: A. B a u m g a r t n e r, Gesinnung, 596n; R. S c h n a c k e n b u r g, Die sittliche Botschaft des Neuen Testaments, T. 1 (Herder TKNT, Suppl. 1), Freiburg-Basel-Wien 1986, s. 40. Ta koncepcja etyczna jest według U. Luza nową wersją nauki Lutra o dwóch królestwach.

${ }^{18}$ R. B u l t m a n n, Jesus, München-Hamburg ${ }^{2} 1965$, s. 68 n. 
w życiu. Nowego Testamentu nie da się użyć jako źródła etyki bez konkretnych przykazań i zasad etycznych, która decyzje moralne pozostawia we wszystkim sumieniu poszczególnego człowieka ${ }^{19}$.

\section{ETYKA „DWUPOZIOMOWA”?}

W tradycji katolickiej znana jest jeszcze inna interpretacja Kazania na Górze. Pragnie ona widzieć w zasadach moralnych Kazania na Górze wskazania dla powołanych do doskonałości, tzn. dla ludzi żyjących w stanie zakonnym, podczas gdy cała rzesza szeregowych, „normalnych" chrześcijan zobowiązana jest jedynie do zachowania Dekalogu, jako swego rodzaju minimum moralnego. Ślady takiej „dwupoziomowej” etyki znaleźć można już w Didache $(6,2)$, gdzie zachowania „całego jarzma Pańskiego” określone jest jako doskonałość, podczas gdy każdy, kto nie jest do tego zdolny, ma się zadowolić zachowaniem tego, co jest dla niego możliwe ${ }^{20}$. Ponieważ dosłowne wypełnienie zasad Kazania na Górze nie mogło być pojmowane jako reguła zobowiązująca wszystkich chrześcijan, kazanie otrzymało range „rady ewangelicznej".

Pogląd, jakoby Jezus od początku sformułował zasady zawarte w Kazaniu na Górze jako rady dla niektórych, nie da się jednak pogodzić z duchem tego tekstu. Nic nie wskazuje na to, że chodzi tutaj o etykę dla wybranych, podczas gdy ogromna rzesza wierzących miałaby się zadowolić zachowaniem jedynie jakiegoś etycznego minimum.

Mimo to pojęcie „rad ewangelicznych” i związanego z nimi stylu życia nie traci nic na wartości, jak ukazuje to H. Schürmann. Nie może tu oczywiście chodzić o jakiejśs stopniowanie moralności. Radykalne normy Ewangelii nie mają, jak twierdzi Schürmann, sensu ascetycznego. Chodzi raczej o znak eschatologicznie-alternatywnego sposobu życia. Jako reprezentanci ludu Bożego niektórzy ochrzczeni ukazują swoim stylem życia obietnice i wymagania Królestwa Bożego. Radykalne wskazania Ewangelii nie są środkami do osiągnięcia doskonałości, ale znakiem świadectwa danego Chrystusowi. Według Schürmanna w łonie ludu Bożego mogą w ten sposób powstać „charyzmatyczne formy życia"21.

19 W. Schrage ostrzega przed próbami szybkiego dopasowania etyki chrześcijańskiej do poglądów moralnych, panujących we współczesnym społeczeństwie, pod pretekstem, że etyka chrześcijańska musi być realistyczna i życiowa. Zob. W. S c h r a g e, Ethik, s. 18.

${ }^{20}$ Zob. też R. S c h n a c k e n b u r g, Vaterunser, s. 22.

${ }^{21}$ Zob. H. S c h ü r m a n n, Jesus - Gestalt und Geheimnis. Gesammelte Beiträge, hrsg. K. Scholtissek, Paderborn 1994, s. 77.81. 


\section{ETYKA PARADYGMATÓW?}

Jeszcze jedną interpretację Kazania na Górze warto tu przedstawić. Bierze ona swoje źródło w zastosowaniu w obrębie teologii pojęcia modelu, pochodzącego z obszaru nauk ścisłych. W etyce powstała w ten sposób koncepcja „etycznego modelu”. Etyczny model pragnie przekazać wartości moralne nie w postaci konkretnych norm moralnych, a w postaci opowiadania czy symbolu (paradygmatu). Wiele mówi się o tzw. „etyce narratywnej”. Takie przekazywanie wartości moralnych umożliwiałoby działanie uwolnione od skostniałych struktur wynikających $\mathrm{z}$ norm moralnych.

Pojęcie etycznego modelu zostało później zastosowane w odniesieniu do wskazań moralnych Nowego Testamentu. Niemiecki egzegeta Josef Blank stwierdził, że w Nowym Testamencie nie ma żadnych ponadczasowych norm moralnych, a jedynie typologiczne punkty odniesienia, które pozwalają ustalić pewną intencję, pewien kierunek. Dopiero na podstawie tak uzyskanych typologii można pytać o to, jak chrześcijanin powinien postępować we współczesnym, zmienionym świecie. Blank nie uważa wcale, aby jego koncepcja prowadziła do rozmycia chrześcijańskiej moralności, a chce jedynie przeciwdziałać naiwnemu fundamentalizmowi, który traktuje Biblię jak kodeks prawny ${ }^{22}$.

Również ta koncepcja nasuwa wiele wątpliwości. Nowy Testament posługuje się wprawdzie często elementami etyki narratywnej, która przekazuje moralne wartości w postaci opowiadań czy porównań (np. przypowieści czy parabole), ale środki te nie wyczerpują absolutnie jej bogactwa. Również Kazanie na Górze posługuje się wieloma przykładami, używa przypowieści i drastycznych obrazów. Wszystkie one jednak muszą być odczytywane w świetle całego nauczania Jezusa i wtedy stają się czymś więcej aniżeli tylko etycznym modelem. Poza tym trzeba stwierdzić, iż Nowy Testament używa częściej etyki argumentującej, a nie jedynie narratywnej i formułuje klarowne zasady postępowania.

${ }^{22}$ J. B 1 a n k, Zum Problem „Ethischer Normen” im Neuen Testament, Conc (niem.) 3 (1967) s. 361nn. W podobnym kierunku idzie koncepcja sformułowana przez P. Hoffmanna i V. Eida, którzy twierdzą, że na podstawie wskazań moralnych Nowego Testamentu można sformułować jedynie „etyczne perspektywy". Zob. P. H of $\mathrm{f} \mathrm{m}$ a $\mathrm{n} \mathrm{n}, \mathrm{V}$. E i d, Jesus von Nazareth und eine christliche Moral. Sittliche Perspektiven der Verkündigung Jesu (QD, 66), Freiburg-Basel-Wien 1975, s. 23-25. Por. też tezę D. Mietha, który mówi o tzw. „etyce narratywnej” Zob. D. M i e t h, Narrative Ethik, FZPhTh 22 (1975) s. 320. 


\section{KONKRETNA MORALNOŚĆ ŁASKI}

We wszystkich dotychczas przedstawionych koncepcjach można było odkryć elementy pozytywne, które niewątpliwie należy wziąć pod uwagę. Koncepcje te nie były jednak w stanie ogarnąc dynamiki wskazań moralnych Kazania na Górze i albo próbowały je za wszelka cenę uczynić radykalnym prawem dla wszystkich, albo też próbowały łagodzić radykalizm tych zasad, ograniczając zakres ich obowiązywania do pewnych sytuacji w życiu pojedynczego chrześcijanina, czy też do pewnej wybranej grupy chrześcijan. Reasumując, można sformułować kilka tez, dotyczących etycznego jądra Kazania na Górze.

Po pierwsze - nauczanie moralne Kazania na Górze, jak całe nauczanie moralne Nowego Testamentu, pragnie pobudzić do konkretnego czynu, przy czym nie jest rzeczą obojętną, jak to postępowanie wygląda. Istnieją w dzisiejszym świecie sposoby zachowań, których nie da się pogodzić z nauką moralną Ewangelii, nawet wtedy, gdy wewnętrzne przekonanie czyniącego byłoby bardzo szlachetne. W Kazaniu na Górze nie chodzi jedynie o etyczne apele czy motywacje, ale o klarowne linie i kryteria postępowania. Pierwotne chrześcijaństwo nie pozwalało sobie na akceptację wszystkiego, co świat antyczny uważał za dobre i szlachetne.

Po drugie - moralność Kazania na Górze jest, jak cała moralność Nowego Testamentu, moralnością łaski ${ }^{23}$. Postępowanie moralne chrześcijanina pozostanie zawsze odpowiedzia na darowaną darmo łaskę zbawienia, wysłużoną przez Chrystusa. Oderwane od perspektywy nowego życia w Chrystusie, ofiarowanego odkupionym, zasady moralne Kazania na Górze przemieniają się w nierealne marzenia, albo też w surowe i przekraczające ludzkie siły normy moralne. Nauka moralna Jezusa kieruje się do ludzi, przemienionych pod wpływem nadchodzącego Królestwa Bożego i zakłada nowe spojrzenie na człowieka, nową antropologię ${ }^{24}$. Nie jest ona moralnością jedynie nakazów i zakazów, bo Bóg, zanim czegokolwiek żąda, najpierw obdarowuje przebaczeniem i łaską. W centrum moralności Kazania na Górze nie stoi zatem naukowy dyskurs na temat argumentatywnej zasadności i wykonalności takiej czy innej normy moralnej, ale - jak

23 J. G. Ziegler sformułował koncepcję moralności łaski („Gnadenmoral”). Zob. J. G. Z i e g 1 e r, In Christus - das Prinzip einer Gnadenmoral, [w:] tenże, In Christus. Beiträge zum ökumenischen Gespräch, St. Ottilien 1987, s. $149 \mathrm{nn}$.

${ }_{24}$ Zob. J. B e c k e r, Das Problem der Schriftgemäßheit der Ethik, [w:] HChrE, Bd. I, s. 251; H. M e r k le i n, Gottesherrschaft, s. 173 nn. 
mówi G. Lohfink - dyskurs na temat Bożego planu zbawienia i jego realizacji na konkretnym etapie historii ludzkości ${ }^{25}$.

Stąd - po trzecie - jest rzeczą niezmiernie istotną, aby poszczególnych zasad Kazania na Górze nie traktować jako norm moralnych, które byłyby oddzielone od całości przepowiadania Jezusa Chrystusa. Wymaganie np. bezkompromisowego pacyfizmu, egalitaryzmu czy bezżeństwa dla wszystkich, w oddzieleniu od całego przepowiadania Chrystusa, nie ma sensu. Cechą przepowiadania Jezusa jest między innymi właśnie fakt, iż moralny imperatyw poprzedzony jest zawsze indykatywem zbawczym, który dopiero umożliwia praktykowanie wysokich wymagań moralnych.

Po czwarte - chociaż zasady moralne Kazania na Górze dotyczą konkretnego postępowania pojedynczych ludzi, nie są to zasady etyki indywidualistycznej. Jak pokazano na początku niniejszego opracowania, Kazanie na Górze skierowane zostało do reprezentantów całego Ludu Bożego jako wezwanie do nowej egzystencji w myśl nowych zasad postępowania. Wymiaru eklezjalnego wymagań moralnych Kazania na Górze nie da się usunąć, ponieważ jednym ze źródeł etycznego poznania chrześcijanina jest wspólnota chrześcijańska - Kościół.

Pozostaje jednak pytanie, które towarzyszy naszym rozważaniom od początku, pytanie o to, w jakim stopniu można realizować zasady Kazania na Górze w codzienności? Czy wszystkie sformułowane w Kazaniu na Górze zasady moralne cieszą się w tym samym stopniu niezmienną i ponadczasową aktualnością? Na pewno nie. Każda z wypowiedzi, również etycznych wypowiedzi Biblii musi przejść niejako przez hermeneutyczne filtry, zanim może być zastosowana $\mathrm{w}$ dzisiejszym kontekście. Jednym $\mathrm{z}$ takich filtrów jest odpowiedź na pytanie jak mocno jakaś wypowiedź związana jest $\mathrm{z}$ centralnymi prawdami Objawienia. Zasady moralne, których negacja oznaczałaby jednoczesne negowanie jakiegoś ważnego momentu Objawienia, zachowują z pewnością ponadczasową i uniwersalną aktualność ${ }^{26}$.

Problem aktualności wypowiedzi etycznych Nowego Testamentu postawił i zbadał H. Schürmann. Rozróżnia on z jednej strony teologiczne lub też eschatologiczne wskazania moralne, które mogą cieszyć się niezmienną aktualnością, jeżeli formułują w sposób ogólny zasady, związane bezpośrednio z przykazaniem miłości. Z drugiej zaś strony Nowy Testament zawiera konkretne zasady dotyczące poszczególnych dziedzin życia, które wymagają już szczegółowego

${ }^{25} \mathrm{G}$. L o h fi n k, Das präegsistente Heilsplan. Sinn und Hintergrund der dritten Vaterunserbitte, [w:] Neues Testament und Ethik, hrsg. H. M e r kl e i n, Freiburg-Basel-Wien 1989, s. 133.

${ }^{26}$ Zob. K. D e m m e r, Moraltheologische Methodenlehre (Studien zur theologischen Ethik, 27), Fribourg-Wien 1989, s. 112; H. W e b e r, Allgemeine Moraltheologie. Ruf und Antwort, Graz-Wien-Köln 1991, s. 82-83. 
osądu, biorącego pod uwagę nie tylko teologiczne punkty widzenia, ale też argumenty rozumowe. Niektóre $z$ takich partykularnych zasad mogą okazać się mocno związane z kulturą, w której powstały. Zamiast wierności literze trzeba wtedy próbować odnaleźć intencję, która przyświecała ich powstaniu i kierując się nią sformułować nowe zasady postępowania, odpowiednie do zmienionych czasów i kultury $^{27}$.

Również radykalne zasady Kazania na Górze, jak pacyfizm czy zakaz sądzenia, nie dadzą się bezpośrednio użyć jako elementu państwowego kodeksu prawnego i mogą być na poziomie społeczeństwa zastosowanie jedynie w sposób intencjonalny. Nie oznacza to jednak, że chrześcijanie powinni zadowolić się stwierdzeniem, że Kazanie na Górze jest w większości niewykonalne. Właśnie na tym polega największe wyzwanie, stojące przed Kościołem naszych czasów, aby świeckiemu społeczeństwu, które nie jest w stanie żyć według zasad Królestwa Bożego ukazać obraz niejako „społeczeństwa kontrastowego” („Kontrastgesellschaft” - G. Lohfink), które jeszcze bardziej wyeliminowałoby ze swojego życia przemoc, wyzysk i nierówność socjalną, które starałoby się przynajmniej zbliżyć do ideału nakreślonego przez Kaznodzieję na Górze Błogosławieństw.

Nie sposób jest wyczerpująco rozwiązać sformułowanej w tytule niniejszego opracowania alternatywy. Kazanie na Górze pozostanie na zawsze profetyczną prowokacją, nie dającą się zamknąć w jakimś kodeksie postępowania. Ale też pozostanie ono na zawsze wyzwaniem dla każdego chrześcijanina, który szuka odpowiedzi na pytanie, jak iść w dzisiejszym świecie w ślady Mistrza z Nazaretu.

Augsburg

KS. MARIAN MACHINEK MSF

Ks. Jan Józef Janicki

\section{PASCHA - CENTRUM ROKU LITURGICZNEGO STAREGO I NOWEGO LUDU BOŻEGO}

W nauczaniu soboru Vaticanum II i Kościoła posoborowego zostało wielokrotnie podkreślone znaczenie misterium paschalnego Chrystusa, które stanowi centralne wydarzenie całej historii zbawienia, a w konsekwencji centrum roku liturgicznego i całego życia

${ }^{27}$ Zob. H. S c h ü r m a n n, Die Frage nach der sittlichen Verbindlichkeit der neutestamentlichen Wertungen und Weisungen. Eine Skizze, [w:] Prinzipien christlicher Moral, hrsg. J. Ratzinger, Einsiedeln 1975, s. 38. 